\title{
PENGENTASAN KEMISKINAN MELALUI KEBIJAKAN POLITIK KELUARGA HARAPAN (Studi Kasus di Ngalukoja Kabupaten Ende)
}

Oleh: Zainur Wula

FISIP Universitas Muhammadiyah Kupang

\begin{abstract}
Abstrak
Penelitian ini bertujuan untuk mengetahui kebijakan pengentasan kemiskinan melalui kebijakan politik keluarga harapan di Ngalukoja-Ende. Penelitian ini merupakan kualitatif dengan pendekatan studi kasus. Pengumpulan data dilakukan melalui wawancara mendalam, observasi dan dokumen, hasil penelitian dianalis secara deskriptif. Bahwa kebijakan pemerintah melakukan bantuan kepada keluarga miskin di desa Ngalukoja sejalan dengan ketentuan dalam Undang-Undang Dasar 1945 dan ketentuan Peraturan Menteri Sosial Republik Indonesia Nomor: tahun 2018, namun dalam implementasinya belum menemui sasaran karena data-data yang disampaikan tidak akurat tentang keluarga miskin. Di samping itu ada keluarga yang mendapat dobel artinya di program bantuan pemerintah yang lainnnya juga tetap mendapat bantuan, padahal yang bersangkutan sudah menerima bantuan program keluarga harahapan. Bahwa kemiskinan timbul disebabkan banyak faktor selain faktor sumber daya alam, namun penyebab kemiskinan yang tersebesar adalah rendahnya sumber daya manusia dan rendahnya semangat kerja, budaya kerja dan etos kerja masyarakat dalam mengelola sumber daya alam yanga ada. Kebijakan pemerintah dalam Program keluarga harapan yang diberikan kepada masyarakat menimbulkan ketergantungan masyaakat terhadap bntuan pemerintah, masyarakat miskin menciptakan malas kerja karena tanpa kerja sudah mendapat banguan pemerintah setiap 3 sampai enam bulan baik berupa dana bantuan PKH maupun beras miskin yang jumlah rata-rata setiap kepala keluarga $45 \mathrm{Kg}$ tiga bulan. Demikian pula dengan settiap keluarga yang telah ditetapkan sebagai penerima Bantuan Langsung Tunai (BLT) akan diberikan bantuan sesuai kriteria dan aturan tertentu dalam periode bulan tertentu yang tiga bulan dan enam bulan sekali.
\end{abstract}

Kata Kunci: Kebijakan Politik, Keluarga Harapan, Pengentasan Kemiskinan.

\section{PENDAHULUAN}

Kemiskinan muncul bersamaan dengan kehadiran manusia dan merupakan salah satu masalah paling mendasar dalam kehidupan manusia itu sendiri. Dewasa ini, berbarengan dengan berkembangnya ilmu-ilmu sosial, kemiskinan dapat dilihat sebagai masalah yang nyata. Pada dua dasawarsa terakhir ini makin banyak dilakukan studi tentang dan sebab-sebab kemiskinan. Meningkatnya perhatian terhadap "dunia ketiga" memegang peranan penting terhadap peningkatan jumlah studi tersebut., tetapi lama kelamaan di lingkungan masyarakat kaya pun kemiskinan tetap hadir.

Jika ditarik ke tahun 1945 hingga tahun 2020 berarti Indonesia telah berusia kurang lebih 75 tahun. Kemerdekaan bangsa Indonesia menjadi titik awal untuk meletakan dasar-dasar fundamental tentang aspek ketahanan nasional dalam berbagai bidang untuk mewujudkan kesejahteraan sosial yang berkeadilan mulai Sabang sampai Merauke, mulai Sanghihe Miangas Sulawesi Utara sampai ke paling selatan 
Indonesia Rote Ndao. Dalam rangka mewujudkan nilai-nilai luhur dan pesan moral kemerdekaan adalah memajukan peradaban bangsa Indonesia melalui berbagai program yang salah satunya adalah bidang perekonomian untuk mengatasi kemiskinan.

Secara sosiologis, kemiskinan berhubungan erat dengan banyak aspek dan saling ketergantungan satu sama lainnya di antaranya hubungan interaktif dan relasi individu, keluarga, masyarakat, pemerintah, birokrasi, jejaring sosial, sumber daya alam, sistem sosial dan budaya, nasional, hubungan internasional, karena manusia adalah episentrum pembangunan dan perubahan sosial budaya. Sebagai agen perubahan sosial budaya, maka pembangunan ekonomi memiliki tujuan akhir yakni meningkatkan pendapatan individu, keluarga, masyarakat, meningkatkan taraf hidup masyarakat, meningkatkan kesejahteraan sosial, terpenuhinya kebutuhan primer dan sekunder lainnnya, meningkatkan status sosial dan hubungan interaksi sosial yang lebih intens, solidaritas sosial, meningkatkan harkat dan martabat kemanusiaan. Untuk mewujdukan tujuan itu masyarakat juga diperhadapkan dengan faktor lainnya seperti sistem sosial budaya, motivasi dan etos kerja serta yang sangat rendah.

Tentu yang menjadi tantangan terbesar disini bukan saja pada tataran manusia dalam aspek fisik semata, tetapi juga mental, karakter, disiplin dan spritualitas manusia untuk menundukan dan memanfaatkan alam dan lingkungan dalam rangka mewujudkan impian hidupnya yaitu peningkatan taraf hidup dan kesejahteraan lahir maupun batin. Kemampuan manusia dalam menundukan alam disini berkaitan dengan kesuburan tanah, topografis, geografis, iklim dan cuaca, kepemilikan lahan dan pemanfaatannnya termasuk peran negara melalui berbagai kebijakan politik pembangunan untuk mengentaskan masyarakat dari belenggu keterbelakangan, kemiskinan dan kesenjangan sosial lainnya.

Sehubungan dengan itu, untuk memahami persoalan kemiskinan di pedesaan yang memiliki saling ketergantungan berkaitan dengan struktur sosial menjadi aspek penting dalam memahami interaksi masyarakat miskin. Interaksi sosial tersebut melahirkan dampak kepada masyarakat yakni satu di antaranya adalah kemunculan kelompok sosial yang memiliki kemampuan dan kelompok sosial lainnnya yang memiliki ketergantungan karena ketidak mampuan secara material. Pada kenyatannnya struktur sosial merupakan kondisi yang memang diciptakan karena proses interaksi manusia dengan lingkungannya. Lebih jauh, struktur sosial ini bisa menghasilkan teknologi dan bahkan sistem hubungan kolektif dan doktrin kebudayaan.

Menurut Miller (1958) sistem sosial tersebut dapat dikelompokkan ke dalam tiga aspek, yaitu keterampilan teknologi, lembaga-lembaga dan kultur. Walaupun begitu yang dominan dalam kehidupan masyarakat miskin ini adalah pada aspek kultur mereka. Oleh karena itulah, maka budaya kerja menjadi faktor penting sebagai usaha nyata dalam kehidupan masyarakat mendorong terwujudnya kehidupan sosial yang lebih baik.

Menurut Wax, M. L, (1971) menjelaskan bahwa kemiskinan berhubungan erat dengan tingkah laku. Ia cenderung mencari penyebab tingkah laku dalam apa yang 
digambarkan sebagai peninggalan suatu subkultur kemiskinan. Ada dua pendekatan langsung berkaitan dengan permasalahan serta kelompok-kelompok dan individu yang menghadapinya. Yang pertama bertolak dari faktor-faktor subkultur, yang cenderung menghalangi penyelesaian masalah kemiskinan. Yang kedua memandang faktor-faktor tersebut justru sebagai akibat dari struktur masyarakat yang dominan dan bertolak dari adanya saling keterkaitan antara berbagai sektor dalam masyarakat tersebut.

Uraian di atas menunjukkan bahwa kemiskinan yang merupakan kekurangan dalam hal material untuk pemenuhan kiebutuhan hidup promer maupun sekunder berhubungan erat dengan budaya kerja individu yang memiliki keterbatasan dalam mengelola tanahnya. Masyarakat cenderung mencari lahan yang subur di samping secara individu tidak memiliki ketermapilan sehingga tidak mampu memanfaatkan teknologi yang ada, rendahnya pengetahuan dalam pengelolaan teknologi tepat guna sebagaimana yang terjadi di Ngalukoja.

Dalam rangka mengatasi masyarakat yang mengalami kesulitan secara ekonomi, pemerintah mengeluarkan kebijakan politik Keluarga Harapan yang saat ini diemplementasikan oleh Kementerian Sosial Repubik Indonesia melalui Dinas Sosial di seluruh Indonesia, salah satunya dengan memberikan bantuan langsung kepada keluarga berpenghasilan rendah di Ngalukoja berdasarkan Peraturan Menteri Sosial Republik Indonesia Nomor: 10 tahun 2017 tentang Program Keluarga Harapan dan diganti dengan Permensos Republik Indonesia No. 1 tahun 2018 tentang Keluarga Harapan.

Menurut Simmel dan Cosser (1965), kemiskinan dapat dilihat dari sudut sosial. Apa yang bersangkut-paut dengan sosiologi adalah kemiskinan, yang diakui sebagai suatu fenomena sosial dan status sosial. Kemiskinan dipandang sebagai suatu sifat dari struktur sosial. Menurut Coser (1965), masyarakat miskin yang modern membentuk lapisan yang pada mulanya heterogen dan yang secara sendiri-sendiri mempunyai banyak ciri yang berbeda-beda. Satu sifat pasif yang penting, yaitu masyarakat memberi reaksi dengan cara tertentu mengikat kalangan miskin menjadi satu golongan. Masyarakat miskin mendapatkan kedudukan sosial tidak dari apa yang mereka lakukan, tetapi dari apa yang dilakukan untuk memenuhi kebutuhan mereka.

Berdasarkan uraian tersebut di atas menunjukkan bahwa kemiskinan merupakan ketidak mampuan masyarakat dalam mengakses potensi lahan untuk pemenuhan kebutuhan primer sekunder, sosial dan kemiskinan memiliki dimensi yang sangat luas serta hubungan yang sangat erat dengan individu, keluarga, masyarakat, pemerintah, politik dan sosial budaya.

\section{METODE PENELITIAN}

Penelitian dilakukan di desa Ngalukoja Kecamatan Maurole Kabupaten Ende, mulai Maret sampai dengan Juni 2020. Objek penelitian ini adalah upaya mengatasi pengentasan kemiskinan dengan kebijakan politik keluarga harapan. Sasaran utama penelitian ini untuk mendeskripkan kebijakan politik program keluarga harapan 
dalam rangka mengentaskan kemiskinan yang dialami masyarakat di desa Ngalukoja Kabupaten Ende. Penelitian didesain secara deskriptif dengan pendekatan studi kasus (Hendrarso, 2005), peneliti ingin mendalam lebih lanjut tentang faktor-faktor yang secara sosiologi mempengaruhi kemiskinan, kebijakan politik pemerintah dalam upaya mengentaskan kemiskinan yag terjadi selama ini, perilaku hidup masyarakat, disiplin, budaya kerja dalam memanfaatkan lahan di Ngalukoja. Pengumpulan data dilakukan melalui observasi, wawancara mendalam. Kegiatan wawancara dengan informan dan observasi dilakukan dengan sedapat mungkin mengakomodir semua peluang perolehan data yang dibutuhkan dengan teknik snowball informan (Creswell, 1994).

Subjek penelitian merupakan keseluruhan informan yang akan diwawancarai kepala keluarga penerima bantuan program keluarga harapan yang dapat memberikan informasi mengenai karakteristik wilayah, pekerjaaan dan kemiskinan, tokoh masyarakat, pemerintahan desa, tokoh pendidikan dan anggota masyarakat. Hasil penelitian ini selanjutnya akan dianalisis secara sosiologis (Asaka \& Awarun, 2020) dalam tradisi kualitatif.

\section{PEMBAHASAN}

Kemiskinan muncul bersamaan dengan kehadiran manusia sejak keberadaan manusia di muka bumi. Berbagai cara yang dilakukan oleh manusia untuk mewujudkan impian hidupnya dengan bekerja keras, mengelola sumber daya alam maupun memanfaatkan kemampuan intelektualnya untuk mengubah cara kerja dalam mewujudkan kebutuhan hidup. Namun dalam kenyataannnya kemiskinan tetap ada meskipun upaya kerja masyarakat dan kebijakan dari pemerintah sudah dilakukan sebagaimana kemiskinan yang yang ada dan dihadapi oleh masyarakat desa Ngalukoja.

Secara geografis desa Ngalukoja di Kecamatan Maurole Kabupaten Ende yang secara demografis saat ini dihuni oleh 147 kepala keluarga (KK) dengan jumlah penduduk sebanyak 882 jiwa. Mata pencahaian utama sebagai petani dan terdapat 7 orang pegawai negeri sipil (ASN) guru. Dari aspek sumber daya alam, desa Ngalukoja merupakan wilayah potensial, memiliki tanah yang subur. Di desa ini terdapat banyak tanaman perkebunan di antaranya kelapa, jambu mente, coklat, kemiri. Penerima Program Keluarga Harapan (PKH) sebanyak 41 Kepala Keluarga. Dari jumlah kepala keluarga sebanyak 147 kepala keluarga, yang menerima dana bantuan langsung tunai (BLT) sebanyak 86 kepala keluarga, penerima beras miskin (Raskin) sebanyak 54 kepala keluarga.

Berdasarkan hasil penelitian menunjukan bahwa kebijakan yang diberikan kepada masyarakat dalam bentuk beras miskin (Raskin), bantuan langsung tunai menyebabkan implikasi dalam kehidupan masyarakat yakni pertama; kebijakan pemerintah dalam dapat memenuhi kebutuhan hidupnya secara baik terutama dalam aspek pemenuhan kebutuhan pokok. Pemerintah memberikan bantuan beras miskin (Raskin) selama enam (6) bulan sekali dengan besaran rata-rata 45 sampai $60 \mathrm{Kg}$ 
perkeluarga. Beras miskin dengan rata-rata 45 sampai $60 \mathrm{Kg}$ per enam bulan di bayar oleh setiap keluarga seharga seribu enam ratus rupiah per-kilogram.

Dari hasil wawancara diperoleh bahwa terkadang masyarakat dan keluarga tertentu ada yang tidak mau menerima bantuan beras miskin yang diberikan, ada yang menyebut mereka malu karena diberi beras dengan harga yang sangat murah sebagaimana ditegaskan oleh Ludgrus M, bahwa kami malu juga mendapat beras murah dengan harga tersebut, sedangkan harga pasaran bisa mencapai sembilan ribu lima ratus rupiah sampai dengan sepuluh ribu ru[iah per-kilogram. Disamping itu ada juga masyarakat dan keluarga yang tidak mau menerima beras miskin (raskin) meskipun sebenarnya memiliki keterbatasan, tetapi umumnya keluarga yang menerima bantuan beras miskin banyak yang menerimanya dan itu hak pribadi setiap keluarga mau menerima atau tidak dan umumnya keluarga harapan menerima beras miskin dengan harga yang sangat murah (wawancara tanggal 15 April 2020).

Selain ada keluarga harapan yang menerima dana bantuan rogram keluarga harapan, ada juga yang tidak mau mengambil beras bantuan pemerintah, selain harganya murah, tetapi keluarga tersebut merasa malu karena terus menerus menerima bantuan dari pemerintah, dan yang tidak mau menerima bantuan itu merasa dirinya sudah mampu mencukupi kebutuhan hidupnya sendiri, tidak mau tergantung lagi pada orang lain, hal ini juga ditegaskan oleh Coser (1965), juga Simmel, seseorang disebut miskin apabila ia dibantu oleh masyarakat lain, karena tidak berhasil atas kemampuan sendiri. Hal ini mengakibatkan bahwa untuk yang miskin telah ditentukan suatu karier khusus, yang mengurangi identitas mereka sebelumnya dan menjadi suatu noda yang menandai pergaulan mereka dengan orang-orang lain. Namun kenyataan yang menyebutkan mereka harus diberi bantuan adalah merendahkan.

Selain itu ada juga keluarga harapan yang menerima dengan senang hati karena memang memiliki kesulitan untuk memperoleh beras, sebagaimana diutarakan oleh informan Gabriel Ngala "jika ada bantuan dari pemerintah jelas kita akan menerima apalagi dengan harga yang terjangkau dan selama ini biasanya kami menerima setiap 3 sampai enam bulan sekali. Setiap tiga bulan tiap keluarga menerima $45 \mathrm{~kg}$ dan jika sampai enam bulan maka memperoleh sebanyak $90 \mathrm{~kg} / \mathrm{kepala}$ keluarga (wawancara tanggal, 9 April 2020).

Implikasi yang kedua; adalah bantuan Program Keluarga Harapan dapat menimbulkan masalah baru yakni menciptakan masyarakat tidak kreatif dan bisa malas. Penerima bantuan akan menjadi malas kerja, tidak mau kerja di kebun dan di sawah. Biasanya pada bulan desember menjelang musim tanam hanya ada sebagian masyarakat yang sibuk dengan persiapan lahan kebun untuk menanam jagung, padi ladang dan palawija, sedangkan sebagian masyarakat yang lainnnya tidak mau bekerja tetapi lebih banyak duduk nongkrong dan sibuk dengam urusan lainnnya yang tidak produktif.

Hal ini disampaikan oleh para informan Yanarius, seorang tokoh masyarakat, yang menyebutkan bahwa sebenarnya bantuan Program Keluarga Harapan itu 
sangat bagus untuk membantu masyarakat miskin, namun terkadang masyarakat menyalahgunakan kebaikan yang dibeikan oleh pemerintah. Bantuan ini sifatnya stumulan, tetapi ternyata dalam pelaksanaannya masyarakat menjadi malas bekerja pada lahan pertanian dan ladang yang masih tersedia dan tanah yang sibur menjadi sia-sia dan menjadi lahan tidur (wawancara 10 April 2020).

Demikian pula ada informan yang menyebut bahwa dengan adanya Program Keluarga Harapan bukannnya kemiskinan berkurang, melainkan angka kemiskinan terus bertambah dari waktu ke waktu. Seharusnya masyarakat harus menyadari bahwa kebijakan pemerintah dalam memberikan bantuan program keluarga harapan adalah satu bentuk perintah dari dari undang-undang dasar 1945, tetapi bukan berarti masyarakat hanya berpangku tangan, seharusnya harus terus bekerja memanfaatkan potensi lahan pertanian dan perkebunan mewujudkan kehudupan yang baik (wawancara dengan ibu Yuliana D, tanggal 11 April 2020).

Dari uraian di atas menunjukan bahwa kemiskinan yang terus bertambah disebabkan oleh rendahnya semangat kerja, etos dan semangat yang selama ini di manjakan dengan berbagai bantuan sosial pemerintah pada hal di wilayah sekitarnya memiliki iklim dan curah hujan yang baik, sumber mata air dan tanah yang subur. Hal ini juga ditegaskan oleh informan yang menyebutkan bahwa dengan adanya bantuan sosial yang terus menerus dilakukan dan diterima oleh masyarakat menyebabkan masyarakat terlena dan tidak mau bekerja, bahkan terlihat rasa malas, menghabiskan waktu dengan banyak kegiatan yang tidak bermanfaat, karena memang masyarakat menganggap bahwa kerja dan tidak kerja sama saja tetap menerima bantuan sama dengan yang lainnnya bekerja keras, mendapat uang dan juga beras. Oleh karena itu agar menjadi bentuk pendidikan dan meningkatkan budaya kerja petani, maka seleksi penerimaan harus ketat, disamping itu pemberian bantuan ada batas waktu, sehingga bida mendorong semangat kerja dan meningkatkan pendapatan serta harkat dan martabat kemanusiaan.

Oleh karena itu pemerintah seharusnya mendorong ke program padat karya, dalam mewujudkan pemerataan pendapatan dan kesejahteraan keluarga. Masyarakat didorong untuk memanfaatkan potensi dan kreativitas tenaga dan akal pikirannnya, semangat kerjanya sehingga lebih memberi arti positif dari keberlangsung pembangunan, sebagaimana ditegaskan oleh Coser (1965) yang menyebutkan harus ada tugas menciptakan kedudukan yang dihargai bagi mereka yang dahulunya merupakan penerima pasif dari bantuan. Penghargaan atas kedudukan itu ialah di mana mereka diminta dan diberi kesempatan memberi sumbangan sosial dan menjadi sekutu aktif dalam suatu usaha bersama yang saling membantu (Coser, 1965). Coser menyebutkan bahwa masyarakat miskin pun mempunyai kemampuan membantu berakhirnya kekuatan yang tidak simetris, yakni bila mereka melepaskan sikap miskin dan membuang peran tingkah laku yang diberikan kepada mereka. Karena itu pemogokan, demonstrasi dan kegiatan-kegiatan politik lainnya dari orang-orang miskin harus dipandang sebagai ikhtiar pengaktifan menuju penyusunan kembali hubungan mereka dalam masyarakat mereka. 
Selain dengan program padat karya, pemerintah juga disarankan untuk memberikan stimulasi dana usuntuk kegiatan produktif lainnya yang selama ini sudah diprogramkan dan perlu ditingkatkan. Yang terpenting dari program ini agar dana tidak sia-sia hilang bahkan sulit dikembalikan, maka dilakukan prosedur dan penataan laksanaan serta sistem pengawasan dan penagihan yang ketat. Hal ini dimaksudkan agar masyarakat diedukasi untuk meningkatkan kreativitas dan daya guna pengetahuan dan ketrampilan untuk meningkatkan kegiatan usahanya mulai dari yang kecil menjadi besar sesuai dengan kemampuan dan akses pasar yang diperoleh.

Hal ini ditegaskan oleh informan bahwa memang perlu bantuan pemerintah untuk mengatasi kemiskinan, tetapi perlu diberi batas waktu, sehingga ada proses pendidikan dan memberi peluang kepada masyarakat untuk meningkatkan kreatifitas keterampilan dalam mengelola pertanian dan menciptakan lapangan kerja sesuai kondisi masyarakat pedesaan dan wilayah huniannnya. Bantuan memang sangat penting tetapi jika dilakukan terus menerus sepanjang tahun kami berkeyakinan dapat menimbulkan kemiskinan jumlah kemiskinan baru.

Berdasarkan ketentuan yang berlaku pemberian bantuan keluarga harapan yang ditetapkan adalah sebagai berikut:

\begin{tabular}{|c|l|c|l|}
\hline \multirow{2}{*}{ No } & \multicolumn{1}{|c|}{ Faktor Penimbang } & \multicolumn{2}{c|}{ IndeksBantuan } \\
\cline { 3 - 4 } & & \multicolumn{1}{|c|}{2019} & \multicolumn{1}{c|}{2020} \\
\hline 1 & Bantuan Tetap PKH Reguler & 550.000 & Tidak Ada \\
\hline 2 & Bantuan Tetap PKH Akses & 1.000 .000 & Tidak Ada \\
\hline 3 & Kategori Ibu Hamil & 2.400 .000 & 3.000 .000 \\
\hline 4 & Kategori Anak usia nol - enam tahun & 2.400 .000 & 3.000 .000 \\
\hline 5 & Kategori Anak SD/Sederajat & 900.000 & $\begin{array}{l}\text { Tidak Ada } \\
\text { Perubahan }\end{array}$ \\
\hline 6 & Kategori Pendidikan Anak SLTP/sederajat & 1.500 .000 & $\begin{array}{l}\text { Tidak Ada } \\
\text { Perubahan }\end{array}$ \\
\hline 7 & Kategori Pendidikan Anak SLTA & 2.000 .000 & $\begin{array}{l}\text { Tidak Ada } \\
\text { Perubahan }\end{array}$ \\
\hline 8 & $\begin{array}{l}\text { Kategori penyandang Disabilitas Berat } \\
\text { (PDB) }\end{array}$ & 2.400 .000 & $\begin{array}{l}\text { Tidak Ada } \\
\text { Perubahan }\end{array}$ \\
\hline 9 & $\begin{array}{l}\text { Kategori lanjut Usia (Lansia) 70 Tahun ke } \\
\text { atas }\end{array}$ & 2.400 .000 & $\begin{array}{l}\text { Tidak Ada } \\
\text { Perubahan }\end{array}$ \\
\hline
\end{tabular}

Berdasarkan tabel tersebut di atas menunjukkan besaran bantuan sosial program keluarga harapan yang diterima sesuai kriteria dan ketentuan yang berlaku. Dalam realisasinya sebagaimana telah diutarakan pada bagian terdahulu berlangsung selama kurun waktu tertentu yakni selama tiga (3) bulan sekali. Dengan besaran angka uang yang diterima disamping bantuan beras yang diberikan setiap tiga bulan secara umum dapat membantu masyarakat miskin untuk memenuhi kebutuhan akan pangan, namun di sisi lain, bantuan sebesar itu jika berlangsung dalam waktu yang 
lama juga dapat menimbulkan ketergantungan masyarakat terhadap pemerintah. Oleh karena itu kebijakan pemerintah melalui program keluarga harapan harus diberikan dalam bentuk proses mengedukasi masyarakat untuk dalam kurun waktu tertentu dapat meninggalkan ketergantungan dan meningkatkan kemandirian dalam hidupnya yakni mengelola lahan di tempat tinggalnya, atau mencari pekerjaan di luar wilayahnya yang dianggap cocok dengan kemampuan sumber daya manusia dan semangat kerjanya.

Secara sosiologis ada dua pendekatan langsung berkaitan dengan kemiskinan yang dihadapi oleh individu dan kelompok sosial. Pertama; bertolak dari faktorfaktor subkultur yang cenderung menghalangi penyelesaian masalah kemis-kinan. Kedua; memandang faktor-faktor tersebut justru sebagai akibat dari struktur masyarakat yang dominan dan bertolak dari adanya saling keterkaitan antara berbagai sektor dalam masyarakat tersebut. Yang mencolok, pada permulaan abad ini George Simmel (1965), melontarkan pendapat yang sangat mirip dengan pendekatan terakhir tersebut. Disebutkan bahwa kemiskinan sebenarnya merupakan gejala yang berhubungan, dalam arti diungkapkan dalam bentuk saling menggantungkan. Pada satu pihak masyarakat miskin menuntut bantuan, di pihak lain golongan kaya mempunyai kewajiban memberi bantuan, dan kewajiban itu menjadi semacam hak. Golongan kaya memberi sedekah untuk keselamatan dirinya sendiri.

Dengan demikian pemberian bantuan tersebut memenuhi kebutuhan individual kedua belah pihak. Simmel melanjutkan dengan suatu kesimpulan bahwa hubungan kaya miskin akan tetap ada didasarkan atas struktur masyarakat. Bersamaan dengan itu struktur tersebut mengakar dalam perbedaan-perbedaan sosial, namun tidak boleh terlalu ekstrim. Karena terpusat pada keadaan sosial seluruhnya; kalangan politik, keluarga, atau kalangan ahli sosiologi, maka tidak ada alasan untuk membantu seseorang lebih dari sekedar mempertahankan status quo, seharusnya penyelesaian yang sesungguhnya atas masalah kemiskinan hanya dapat direalisasikan bertolak dari perubahan-perubahan keadaan sosial menyeluruh dan mendasar dari masyarakat setempat khususnya keluarga miskin penerima bantuan program keluarga harapan.

Oleh karena itu bantuan yang diberikan oleh pemerintah dalam rangka pengentasan kemiskinan harus diapresiasi dengan baik oleh masyarakat sebagai bantuan awal, stimulan untuk mengurangi beban kemiskinan yang selanjutnya masyarakat harus berupaya sekuat tenaga mendayakgunakan lahan mewujudkan pendapatan dan mengurangi kemiskinan. Kemiskinan yang terlihat di masyarakat Ngalukoja pada dasarnya adalah kemiskinan cultural aau budaya kemiskinan, karena sumber daya akambya sangat baik, tetapi kelemahan yang terkihat adalah kurangnya inisiatif, reandahnya budaya kerja, etis kerja dan kemampuan kreativitas dalam rangak mewujudkan tujuan hidup secara maksimal. Dari sinilah terlihat bahwa jika bantuan ini diberikan secara terus menerius tanpa batas waktu dan mengedukasi masyarakat, maka kemiskinan bertambah.

Dengan demikian program padat karya harus diciptakan, pelatihan ketenagaan 
kerja, kursus dan diklat pertanian, perkebunan, pemberian modal bergulir, peningkatan usaha mikro kecil dan menengah (UMKM) ini cara terbaik dalam rangka memutus mata rantai ketergantungan masyarakat terhadap bantuan pemerintah dalam bentuk jaringan pengamanan sosial program keluarga harapan dan bantuan langsung tunai lainnnya. Cara seperti ini juga dapat meningkatkan kemandirian masyarakat harkat dan martabat kemanusiaan dalam mewujdukan kehidupan yang baik yakni dapat keluar dari belenggu kemiskinan.

\section{PENUTUP}

Kebijakan pemerintah melakukan bantuan kepada keluarga miskin di desa Ngalukoja sejalan dengan ketentuan dalam undang-undang Dasar 1945 dan ketentuan Peraturan Menteri Sosial Republik Indonesia Nomor: tahun 2018, namun dalam implemenntasinya belum menemui sasaran karena data-data yang disampaikan tidak akurat tentang keluarga miskin. Di samping itu ada keluarga yang mendapat dobel artinya di program bantuan pemerintah yang lainnnya juga tetap mendapat bantuan, padahal yang bersangkutan sudah menerima bantuan Program Keluarga Harahapan.

Kemiskinan timbul disebabkan banyak faktor selain faktor sumber daya alam, namun penyebab kemiskinan yang tersebesar adalah rendahnya sumber daya manusia dan rendahnya semangat kerja, budaya kerja dan etos kerja masyarakat dalam mengelola sumber daya alam yanga ada. Kebijakan pemerintah dalam Program keluarga harapan yang diberikan kepada masyarakat menimbulkan ketergantungan masyaakat terhadap bntuan pemerintah, masyarakat miskin men-ciptakan malas kerja karena tanpa kerja sudah mendapat banguan pemerintah setiap 3 sampai enam bulan baik berupa dana bantuan PKH maupun beras miskin yang jumlah ratarata setiap kepala keluarga $45 \mathrm{Kg}$ tiga bulan. Demikian pula dengan settiap keluarga yang telah ditetapkan sebagai penerima bantuan langsung tunai (BLT) akan diberikan bantuan sesuai kriteria dan aturan tertentu dalam periode bulan tertentu yang tiga bulan dan enam bulan sekali.

\section{DAFTAR PUSTAKA}

Asaka, D.S. \& Awarun, O. (2020). Understanding Mechanistic Explanation as A Strategy of Analytical Sociology. Indonesian Journal of Social and Environmental Issues (IJSEI), 1(3), 192-198.

Biro Pusat Statistik. (2019). Data Kemiskinan di Indonesia. Jakarta.

Chambers, D. F. (1982). Perencanaan Pembangunan Ekonomi Bangsa. Jakarta: Pustaka Jaya.

Chapelli. (1940). Kebidupan Sosial dan Perubahan Budaya Kerja. Ontario-Lilionis University Press.

Creswell, J. (1994). Research Design: Qualitative and Quantitative Approach. Oslo: Sage Publications.

Coser, L. (1965). The Sociology of Poverty. Social Problems. Vol. 13. 
Kompas, 18 September 2014. Kebijakan Pemerintah RI tentang Perlindungan Sosial kepada Rumah Tangga Miskin di Indonesia dan BPJS.

Miller, W. (1958). Lower Class Culture as a Generating Milieu of Gang Delinquency. Journal of Social Issues, No. 14.

Peraturan Menteri Sosial Republik Indonesia Nomor: 10 tahun 2017 tentang Program Keluarga Harapan.

Peraturan Menteri Sosial Republik Indonesia Nomor: 1 tahun 2018 tentang Program Keluarga Harapan.

Pratedjasastra. (1989). Kebutuban Dasar dalam Perspektif Pembangunan. Yogyakarta: Gajah Mada University Press.

Simmel, G. (1908). Der Arme dalam "Sociologie: Untersucchungen caber die Farmen der Vergeseliscahaftung, "The poor", door Claire Jacobson, dalam Social Problems, Vol. 13, No. 2.

Susanti Emy Hendrarso. (2005). Penelitian Kualitatif Sebuah Pengantar. Jakarta: Kencana Prenada Media Group.

Wax, M. L. (1971). Poverty and Interdependency; dalam Leacock.

Undang-Undang Republik Indonesia Nomor: 40 tahun 2004 tentang Sistem Jaminan Sosial Nasional, Jakarta, Sekretariat Negara RI

Bertrand, A. L.: Poverty as Relative Deprivation dalam "Journal of Human Relations"; vol. 15, 1967; hlm. 155 - 158.

Harrington, M. (1962). The other America: Poverty in the United States. New York: Macmillan.

SK Direktur Jenderal Perlindungan dan Jaminan Sosial tentang Petunjuk Teknis Penyaluran Bansos Non Tunai PKH Tahun 2020 Nomor 04/3/OT.02.01/ $1 / 2020$. 